\title{
(DIS)ADVANTAGES OF DECENTRALIZATION MODELS DRIVEN BY NON-ECONOMIC REASONS: THE CASE OF BOSNIA AND HERZEGOVINA
}

Aida Soko

\section{Abstract}

This paper uses a DEA-VRS methodology for the estimation of municipal efficiency to provide empirical evidence of the impact of decentralization in BiH under the Dayton Peace Agreement (DPA) on overall municipal efficiency. In particular, the paper focuses on the analysis of the overall efficiency of 33 new municipalities established under DPA. The findings suggest that the average municipal efficiency in BiH is rather low, and only 23 or $16 \%$ of municipalities in BiH are efficient. The average efficiency achieved is around 0.71 . This means that with the same level of inputs (budget revenue) outputs may be increased by almost 30\%, on average. The results of DEA-VRS efficiency estimation suggest that new municipalities have lower average efficiency (0.60) in comparison to "older" municipalities (0.74). In our sample, only six percent of newly created municipalities are efficient, $12 \%$ exhibit some level of efficiency, while the remaining $82 \%$ are inefficient, with significant share (39\%) of very inefficient municipalities.

Key words: decentralization, municipal efficiency, local communities, public services, data envelopment analysis

JEL classification: $H 77, H 11$

\section{INTRODUCTION}

The first decentralization steps in Bosnia and Herzegovina $(\mathrm{BiH})$ were taken in the late 90s (19951999) when entity laws on local government were adopted. Further modernization of the decentralization framework was done due to the requirements of the Stabilisation and Association Process to the European Union (EU), and a new set of laws were adopted in 2004-2006, embedding some of the key principles of the European Charter into legislation.

The current decentralization framework in $\mathrm{BiH}$ is the result of the Dayton Peace Agreement (DPA) and the historical heritage of the former Yugoslavia. Yugoslavia was a decentralized state with weak central power and relateively powerful federal republics. Among the countries that arose from the former Yugoslav republics, $\mathrm{BiH}$ is the only one that has no prevailing ethnic group. Therefore, recreating the Yugoslav approach to accommodating different ethnic groups was a logical choice for the $\mathrm{BiH}$ constitution (Schoepflin 1993, Burg and Shoup 1999, Hayden 2005).

$\mathrm{BiH}$ is composed of two entities and one district. The central government has limited jurisdiction and consists of a Council of Ministers chaired by the

\section{Aida Soko}

PhD Student

School of Economics and Business,

University of Sarajevo

E-mail: aidasba@hotmail.com 
President of the Council. There is also a rotating threemember presidency and bicameral parliament at the state level. Two major mechanisms guarantee ethnic representation: quotas in the government and civil service, and veto rules at the parliament level.

Major responsibilities rest at the entity and district level. The entities, the Federation of Bosnia and Herzegovina ( $\mathrm{FBiH})$ and the Republika Srpska (RS), are politically, administratively and fiscally autonomous and have their own constitutions, governments and bicameral parliaments. $\mathrm{FBiH}$ is more decentralized and is composed of ten cantons, each having its own government and parliament, while municipalities have a mayor and an assembly. In the RS, there are only two tiers of government: the entity level and municipalities. FBiH's structure is marked by vertical and horizontal decentralization, which is reflected in its fiscal arrangements and budgetary structures. However, vertical and horizontal cooperation between different levels in quite poor. The efficiency of municipality services provision therefore depends on a number of factors, of which many are not under municipal control. Political compromises in $\mathrm{BiH}$ have resulted in complex solutions, which in turn became the usual excuse for failures in increasing the efficiency of municipalities or boosting private sector initiatives. Political deadlock at the state level is, in fact, a huge problem, but too often is used as a justification for the lack of reforms at the sub-national government level. The positive examples of reforms may be found in the public sector at the level of local communities, as well as a number of successful businesses with different backgrounds, (privatization, green field, local, international) which also confirms that success is possible in spite of difficult conditions.

Decentralization is a complex process and even more complex in $\mathrm{BiH}$ due to asymmetric solutions throughout the country and the mix of centralization and decentralization of important administrative, development and financing responsibilities. Therefore, municipal efficiency in $\mathrm{BiH}$ needs to be analyzed, taking into consideration constitutional design and historical, ethnic and cultural factors that shape the administrative set up of the country.

The paper is organized as follows. Section 1 provides review of relevant literature and studies to establish a background for the selection of appropriate methods and data discussed in Section 2. An estimation of municipal efficiency for $\mathrm{BiH}$ municipalities is presented in Section 3, followed by a discussion of empirical findings in Section 4. The paper concludes by summarizing key empirical findings.

\section{REVIEW OF RELEVANT LITERATURE AND STUDIES}

The role of the state and the form in which it is exercised is probably the most discussed topic among economists, scholars, policy makers and development professionals. This debate has become more and more complex due to globalization and new views on democratic governance. Despite disputes on its positive effects, decentralization is still one of the core recommendations by international institutions on achieving democratic and effective governance.

Fiscal federalism and decentralization became a hot topic among economists in the 1980s and 1990s due to the need for better allocation of public spending and better efficiency of government structures. Decentralization was driven by different reasons, ranging from the pure need for more efficient public spending to address macroeconomic problems (Argentina, Brazil, India, Nigeria) to it use as a tool to provide more independence to certain regions addressing different cultural, ethnic and political issues (Canada, Switzerland, Belgium, China, Russia, Ethiopia). In general, there are three major types of decentralization: political, fiscal and administrative. Political decentralization involves the transfer of political authority to a lower, local level of government, fiscal decentralization deals with the decentralization of tax collection, while administrative decentralization seeks to decentralize authority, responsibility and financial resources in providing public services (UNDP 2008, Klun 2004, Raboca et al. 2010, Cadez and Czerny 2010).

The best arrangement in balancing fiscal power and responsibilities between different levels of government is always country-specific and adjusted to the local context. There is no one, best solution, but there are certain rules and working mechanisms worldwide. Well-designed decentralization may result in a number of advantages, such as: increased democratization (Conyers 1984, Thiessen 2003), simplified bureaucracy (Klugman 1994, Martinez-Vasquez and Mc Nabb 2003), better political representation in decision making (Levy 2006, Treisman 2002), increased political stability (Wolff 2012, Simonsen2005), better specialization within the central government (Brennan and Buchanan 1980, Breton 1983), increased quality of public services (Tiebout 1956, Musgrave 1959, Oates 1972); and better accountability at all tiers of government (Dabla-Noris 2006, Ebel and Yilmaz 2002). At the other end, some of the most common unwanted results of decentralization are: new charges -quasi taxes imposed by local governments (Prud'homme 1995, Shah 2004; Smoke 2013), fragmentation of internal markets (Dabla-Norris and Wade 2002, Seabright 
1996); increased corruption (Rodriguez-Pose and Gill 2003, Mauro 1995, Levy 2006, Kolstad and Fildstad 2006), cross-subsidizing/allocation formulas (Ebel and Yilmaz 2002, Kalb 2010, Brueckner 1982), increased complexity of tax reforms (Bird 2010, Fjeldstad and Moore 2008), conflict with macroeconomic policy (World Bank n.d., Meloche et al. 2004) and increased public employment (Alesina et al. 2002, Jin and Zou 2002).

The findings of studies on decentralization effects are rather mixed, but in principle confirm effects that are more positive. The findings confirm the positive impact of decentralization on: education, population density, political concentration and the share of services bought from the private sector. Negative impacts have been identified among local tax rate levels, personal income levels, transfers from the central government, distance to capital/regional centre, and unemployment levels (Afonso and Fernandes 2008, Balaguer-Coll, Tortosa-Ausina and Prior 2007, Loikkanen, Susiloto and Funk 2011, Mahabil 2011, Nieswand and Seiferd 2011).

In principle, decentralization brings efficiency in the allocation of public services and in turn should have a positive impact on economic growth. However, studies show both positive and negative correlations between decentralization and economic growth depending on the measure used. A positive correlation is found when measuring growth by per capita income and accounting for cultural and other differences between countries (Martinez-Vazquez and McNab 2003, Akai and Sakata 2002, Bird and Vaillancourt 1998). At the same time, a negative correlation with economic growth has been found with spending share net of intergovernmental transfers used as a measure (Davoodi and Zou 1998). Relevant to the BiH context, the inverse relation between GDP per capita growth and ethno-linguistic fractionalization is confirmed by a number of studies (Easterly and Levine 1997, Canning and Fay 1993, Mauro, 1995, La Porta et al. 1999).

Studies on performance measurement have been developed as part of an organization theory related to effective work organization (Taylor 1911), the nature of bureaucracy (Weber 1922) and concept of efficiency (Simon 1946). In measuring the performance of the public sector, two major avenues are possible: individual services/institutions/agencies and the overall performance of a certain level of the government. The use of performance measurement tools at the individual level seems to be easier for exploration, while measuring overall performance is much more complex. Nevertheless, both avenues require a performance framework with specific indicators measured in regular intervals. It should not be a traditional one-off evaluation or analysis, but should become a routine in tracking the progress of government in accomplishing goals and desired outcomes.

In discussing the efficiency measurement of local communities, the starting point should be a basic rule of efficiency: ensuring the maximum output with a given level of inputs (Koopmans 1951, Lovell 1993). This means that if one community may transform the given inputs with a certain output, then other communities shall be able to do the same, and if they cannot then efficiency must be the issue. In practice, it is not that simple, as there are many factors not under the control of local communities. Therefore, the effectiveness and efficiency of decentralization is measured by closeness to the optimum level of established mechanisms whereby the public provision of goods and services is provided through a smooth mechanism of intergovernmental collaboration, which is most beneficial to citizens (Lane 2000).

The findings of municipal efficiency research can be divided into two large groups: efficiency in the provision of individual public services and overall municipal efficiency. Among individual public services, the most explored are utility services (waste, sewage, water, and energy), hospitals, elderly care and infrastructure maintenance. The efficiency of public service provision is indeed an important part of municipal overall efficiency, but does not allow for an assessment of overall local government performance and efficiency.

The findings of studies related to overall municipal efficiency estimation are rather mixed and rarely find patterns, confirming that national specifics have a high impact on efficiency scoring. In general, smaller local communities with homogeneous populations are better positioned to serve the preferences of their inhabitants. However, too small jurisdictions face the lack of a fiscal base, cannot exploit economy to scale, and often are exposed to a lack of managerial competence and experience among staff (Mill 1861, Musgrave 1959, Oates 1972, Tullock 1969).

\section{METHODS AND DATA}

The selection of research methodology and data is a key milestone in getting relevant results and providing valuable outcomes, conclusions and recommendations. The estimation of overall municipal efficiency must address specific country conditions, the government structure, socio-economic factors, ethnic diversity and many other aspects. In particular, the fragmented statistical system and data collection in $\mathrm{BiH}$ makes the selection of data even more complex. Therefore, the final selection of inputs and outputs for 
the municipality efficiency estimation in BiH is based on a desk review of relevant studies on overall municipal efficiency and the most frequently used methods and data.

Efficiency estimation may be done by using deterministic approaches or stochastic frontier models. Deterministic approaches interpret whole deviation from best practice frontier as inefficiency, while stochastic frontier models provide a decomposition of deviation into inefficiency and a stochastic term (Deprins and Simar 1983). Depending on the assumed distribution, the methods may be parametric or nonparametric. Parametric methods are used where the assumed distribution is normal and assumed variance is homogenous, while nonparametric methods may be applied to any assumed distribution and any assumed variance. By definition, parametric methods establish a best practice frontier against which deviations may be measured, while in the nonparametric approach the best practice frontier is generated by tight data enveloping.
Due to the number of advantages over parametric methods, non-parametric methods are the most often used methods in the analysis of municipal efficiency. The major advantages of nonparametric methods are: greater flexibility (no need for any specification of functional form of the frontier in advance), less-restrictive assumptions, and the possibility of handling multiple inputs and multiple outputs in a simple way. The disadvantages of non-parametric methods are their deterministic nature in interpreting all deviations from the frontier as inefficiency without allowing for statistical noise, difficulties in making statistical inference and their sensitivity to outliers (Ruggiero 2007).

There are a very limited number of studies on overall municipal efficiency, and therefore the selection of method and input and output data for this study is based on a desk review of 35 studies on overall municipal efficiency in European countries. Table 1 provides an overview of these studies with the methods and data used for municipal efficiency estimation.

As presented in Table 1, the authors mainly used

Table 1: Municipal efficiency studies

\begin{tabular}{|c|c|c|c|c|}
\hline Country & Researchers & Method & Input variable & Output variables \\
\hline Belgium & $\begin{array}{l}\text { De Borger et al. } \\
\text { (1994) }\end{array}$ & $\mathrm{FDH}$ & $\begin{array}{l}\text { Personnel Capital } \\
\text { and Financial } \\
\text { expenditures }\end{array}$ & $\begin{array}{l}\text { Population, length of municipal roads, recreational facili- } \\
\text { ties, primary and secondary education, grants beneficiaries }\end{array}$ \\
\hline Belgium & $\begin{array}{l}\text { De Borger and } \\
\text { Kerstens (1996) }\end{array}$ & $\begin{array}{l}\text { DEA and } \\
\text { FDH }\end{array}$ & $\begin{array}{c}\text { Total } \\
\text { expenditures }\end{array}$ & $\begin{array}{l}\text { Population, grant beneficiaries, pupils in primary school, } \\
\text { public recreational facilities, population }>65 \text { years }\end{array}$ \\
\hline Belgium & $\begin{array}{l}\text { Coffe and Geys } \\
\quad(2005)\end{array}$ & DEA & $\begin{array}{l}\text { Total } \\
\text { expenditures }\end{array}$ & $\begin{array}{l}\text { Population, recreational facilities, primary and secondary } \\
\text { education, grants beneficiaries, elderly care }\end{array}$ \\
\hline Belgium & Geys (2006) & SFA & $\begin{array}{l}\text { Current } \\
\text { expenditures }\end{array}$ & $\begin{array}{l}\text { Length of municipal roads, recreational facilities, primary } \\
\text { and secondary education, grants beneficiaries }\end{array}$ \\
\hline Belgium & $\begin{array}{c}\text { Geys and Moesen } \\
\text { (2009) }\end{array}$ & SFA & $\begin{array}{l}\text { Current } \\
\text { expenditures }\end{array}$ & $\begin{array}{l}\text { Grant beneficiaries, pupils in primary school, public recrea- } \\
\text { tional facilities, length of municipal roads, waste collection }\end{array}$ \\
\hline Belgium & $\begin{array}{l}\text { Ashworth et al } \\
\text { (2014) }\end{array}$ & DEA & $\begin{array}{l}\text { Total } \\
\text { expenditures }\end{array}$ & $\begin{array}{l}\text { Municipal roads, waste collection, recreational facilities, } \\
\text { primary and secondary education, grants beneficiaries, } \\
\text { elderly care, }\end{array}$ \\
\hline $\begin{array}{l}\text { Czech } \\
\text { Republic }\end{array}$ & $\begin{array}{c}\text { Stasna and Gregor } \\
(2011)\end{array}$ & $\begin{array}{l}\text { DEA and } \\
\text { SFA }\end{array}$ & $\begin{array}{c}\text { Current } \\
\text { expenditures }\end{array}$ & $\begin{array}{l}\text { Population, population }>65 \text { years, pupils in primary school } \\
\text { cultural facilities, municipal roads, bus stations, municipal } \\
\text { police, arable land. }\end{array}$ \\
\hline $\begin{array}{l}\text { Czech } \\
\text { Republic }\end{array}$ & $\begin{array}{c}\text { Stasna and Gregor } \\
(2015)\end{array}$ & DEA /SFA & $\begin{array}{l}\text { Current } \\
\text { expenditures }\end{array}$ & $\begin{array}{l}\text { Municipality built area, length of municipal roads, waste } \\
\text { collection, sport facilities, cultural facilities, parks and } \\
\text { green areas, kindergartens, primary and secondary edu- } \\
\text { cation, elderly care, social services, public safety, public } \\
\text { transport }\end{array}$ \\
\hline Finland & $\begin{array}{l}\text { Loikkanen and } \\
\text { Susiluoto (2005) }\end{array}$ & DEA & $\begin{array}{l}\text { Current } \\
\text { expenditures }\end{array}$ & $\begin{array}{l}\text { Children's care centres, municipal libraries, teaching hours } \\
\text { in comprehensive and senior schools, institutional handi- } \\
\text { capped and elderly care, dental and health care }\end{array}$ \\
\hline Finland & $\begin{array}{l}\text { Loikkanen et al. } \\
\qquad(2011)\end{array}$ & DEA & $\begin{array}{l}\text { Current } \\
\text { expenditures }\end{array}$ & $\begin{array}{l}\text { Libraries, health care, primary and secondary education, } \\
\text { rants beneficiaries, children care, social services, }\end{array}$ \\
\hline France & $\begin{array}{l}\text { Nieswand and } \\
\text { Seiferd (2011) }\end{array}$ & DEA & $\begin{array}{c}\text { Total } \\
\text { expenditures }\end{array}$ & Administration, roads, secondary education, social services \\
\hline
\end{tabular}




\begin{tabular}{|c|c|c|c|c|}
\hline $\begin{array}{c}\text { FYR } \\
\text { Macedonia }\end{array}$ & $\begin{array}{l}\text { Nikolov and } \\
\text { Hrovatin (2013) }\end{array}$ & DEA /SFA & $\begin{array}{c}\text { Current } \\
\text { expenditures }\end{array}$ & $\begin{array}{l}\text { Population by age categories as a proxy of different ser- } \\
\text { vices and length of asphalt roads }\end{array}$ \\
\hline Germany & Geys et al. (2013) & SFA & $\begin{array}{l}\text { Current } \\
\text { expenditures }\end{array}$ & $\begin{array}{l}\text { Population, population }>65 \text { years, pupils in public schools, } \\
\text { kindergartens, public recreational facilities, number of } \\
\text { employees }\end{array}$ \\
\hline Germany & Kalb (2012) & SFA & $\begin{array}{l}\text { Current } \\
\text { expenditures }\end{array}$ & $\begin{array}{l}\text { Population, population }>65 \text { years, pupils in public schools, } \\
\text { number of employees }\end{array}$ \\
\hline Germany & $\begin{array}{l}\text { Bischoff et al. } \\
\qquad(2013)\end{array}$ & DEA /FDH & $\begin{array}{l}\text { Personnel, } \\
\text { Capital and } \\
\text { Financial } \\
\text { expenditures }\end{array}$ & $\begin{array}{l}\text { Population, recreational facilities, primary and secondary } \\
\text { education, care for children, business development }\end{array}$ \\
\hline Greece & $\begin{array}{l}\text { Athanassopoulos } \\
\text { and Triantis (1998) }\end{array}$ & $\begin{array}{l}\text { DEA and } \\
\text { SFA }\end{array}$ & $\begin{array}{l}\text { Current } \\
\text { expenditures }\end{array}$ & $\begin{array}{l}\text { Population, municipality built area, environmental } \\
\text { protection }\end{array}$ \\
\hline Greece & $\begin{array}{l}\text { Doumpos and } \\
\text { Cohen }(2014)\end{array}$ & DEA & Own revenues & Street lightening, municipal roads, recreational facilities, \\
\hline Italy & Boetti et al. (2012) & SFA & $\begin{array}{l}\text { Current } \\
\text { expenditures }\end{array}$ & $\begin{array}{l}\text { Population, length of roads, waste collected, pupils in kin- } \\
\text { dergarten, primary and secondary school, population }>75 \\
\text { years }\end{array}$ \\
\hline Italy & Lo Storto (2013) & DEA & $\begin{array}{l}\text { Cur } \\
\text { expen }\end{array}$ & $\begin{array}{l}\text { Population, municipal built area, municipal roads, kinder- } \\
\text { gartens, environmental protection }\end{array}$ \\
\hline Italy & Carosi et al. (2014) & DEA & $\begin{array}{l}\text { Current } \\
\text { expenditures }\end{array}$ & $\begin{array}{l}\text { Population, municipal roads, kindergarten, primary and } \\
\text { secondary education, elderly care }\end{array}$ \\
\hline Italy & $\begin{array}{l}\text { Agasisti et al. } \\
\quad(2015)\end{array}$ & DEA & $\begin{array}{l}\text { Current } \\
\text { expenditures }\end{array}$ & $\begin{array}{l}\text { Population, municipal roads, waste collection, public } \\
\text { safety, }\end{array}$ \\
\hline Italy & Lo Storto (2016) & DEA & $\begin{array}{c}\text { Current } \\
\text { expenditures }\end{array}$ & Population, municipal built area, municipal roads, \\
\hline Portugal & $\begin{array}{l}\text { Afonso and } \\
\text { Fernandes (2008) }\end{array}$ & DEA & $\begin{array}{l}\text { Current } \\
\text { expenditures }\end{array}$ & $\begin{array}{l}\text { Municipal performance in administration, education, so- } \\
\text { cial and cultural services, waste collection and environ- } \\
\text { mental protection }\end{array}$ \\
\hline Portugal & $\begin{array}{l}\text { Da Cruz and } \\
\text { Marques (2014) }\end{array}$ & DEA & $\begin{array}{l}\text { Personnel, Capital } \\
\text { and financial } \\
\text { expenditures }\end{array}$ & $\begin{array}{l}\text { Population, municipal roads, waste collection, sewerage } \\
\text { system, water supply, recreational facilities }\end{array}$ \\
\hline Portugal & $\begin{array}{l}\text { Cordero et al. } \\
\quad(2016)\end{array}$ & $\begin{array}{c}\text { Conditional } \\
\text { efficiency }\end{array}$ & $\begin{array}{c}\text { Total } \\
\text { expenditures }\end{array}$ & $\begin{array}{l}\text { Population, administrative services, waste collection, wa- } \\
\text { ter supply }\end{array}$ \\
\hline Serbia & $\begin{array}{l}\text { Radulović and } \\
\text { Dragutinović } \\
\qquad(2015)\end{array}$ & SFA & $\begin{array}{l}\text { Current } \\
\text { expenditures }\end{array}$ & $\begin{array}{l}\text { Population, municipal roads, water supply, kindergartens, } \\
\text { primary and secondary education, social services }\end{array}$ \\
\hline Spain & $\begin{array}{l}\text { Bosch-Roca et al. } \\
\qquad(2012)\end{array}$ & DEA & $\begin{array}{r}\text { Cur } \\
\text { expen }\end{array}$ & Total output \\
\hline Spain & $\begin{array}{l}\text { Benito et al. } \\
\qquad(2010)\end{array}$ & DEA & $\begin{array}{l}\text { Current } \\
\text { expenditures }\end{array}$ & $\begin{array}{l}\text { ater supply, sport facilities, cultural fa- } \\
\text { ks and green areas public safety, }\end{array}$ \\
\hline Spain & $\begin{array}{l}\text { Cuadrado- } \\
\text { Ballesteros et al. } \\
\text { (2013) }\end{array}$ & DEA & $\begin{array}{l}\text { Current } \\
\text { expenditures }\end{array}$ & $\begin{array}{l}\text { Population, municipality built area, administrative servic- } \\
\text { es, social services, public safety, environmental protection }\end{array}$ \\
\hline Spain & $\begin{array}{c}\text { Zafra-Gomez } \\
\text { and Muniz-Perez } \\
(2010)\end{array}$ & DEA & $\begin{array}{c}\text { Current } \\
\text { expenditures }\end{array}$ & $\begin{array}{l}\text { Population, street lightening, municipal roads, waste col- } \\
\text { lection, parks and green areas }\end{array}$ \\
\hline Spain & $\begin{array}{l}\text { Balaguer-Coll et } \\
\text { al. (2013) }\end{array}$ & DEA FDH & $\begin{array}{c}\text { Total } \\
\text { expenditures }\end{array}$ & $\begin{array}{l}\text { Population, no. of lighting points, tons of waste, street in- } \\
\text { frastructure area, public parks area, quality of services }\end{array}$ \\
\hline Spain & $\begin{array}{l}\text { Perez-Lopez et al. } \\
\qquad(2015)\end{array}$ & DEA & $\begin{array}{l}\text { Current } \\
\text { expenditures }\end{array}$ & $\begin{array}{l}\text { Population, municipality built area, street lightening, } \\
\text { waste collection, water supply, parks and green area }\end{array}$ \\
\hline Slovenia & Pevcin (2014a) & SFA & $\begin{array}{c}\text { Total } \\
\text { expenditures }\end{array}$ & $\begin{array}{l}\text { Population, primary and secondary education, elderly } \\
\text { care, business development }\end{array}$ \\
\hline Slovenia & Pevcin (2014b) & $\begin{array}{l}\text { DEA and } \\
\text { SFA }\end{array}$ & $\begin{array}{c}\text { Total } \\
\text { expenditures }\end{array}$ & $\begin{array}{l}\text { Population, primary and secondary education, elderly } \\
\text { care, business development }\end{array}$ \\
\hline Turkey & $\begin{array}{l}\text { Kutlar and Bakirci } \\
\qquad(2012)\end{array}$ & DEA & $\begin{array}{l}\text { Total } \\
\text { expenditures }\end{array}$ & $\begin{array}{l}\text { Population, health, primary and secondary education, el- } \\
\text { derly care }\end{array}$ \\
\hline
\end{tabular}

Source: own compilation 
Data Envelopment Analysis (DEA) as their primary research method, the second-most used method is Stochastic Frontier Analysis (SFA), while in a few cases the authors used Free Disposal Hull (FDH). The common measure of input for efficiency is either total or current budget expenditure. In several studies, in addition to total or current expenditure, personal, capital and financial expenditures are used as an input variable as well. In terms of output data, the most frequently used are population, the number of pupils in primary schools, length of roads, number of grant beneficiaries, and the share of the elderly.

In the process of selecting an appropriate method for BiH municipalities' efficiency estimation, the advantages and disadvantages of the three methods (SFA, FDH and DEA) have been considered and DEA has been chosen as the proper method for this study. The reasons are found in the sample size (the sample includes all but one local community in $\mathrm{BiH}$, with a total number of units analyzed of 141), the lack of panel data, its flexibility to be used in any distribution and specification assumption, and allowance for the usage of multiple inputs and outputs in the development of different scenarios.

Data Envelopment Analysis (DEA) is a non-parametric method for frontier estimation proposed by Farrell in 1957 and further developed by Charnes, Cooper and Rhodes in 1978, when the term DEA was coined. DEA identifies the efficient unit, which represents the frontier, and inefficient units, which remain below the frontier line. The distance from the frontier and all deviations from the frontier represent inefficiency. DEA allows for estimation by using constant return to scale (CRS) and variable return to scale (VRS). The CRS DEA model works under the assumption that DMUs operate at optimal scale and allows for the estimation of overall technical efficiency without variations in returns to scale. As this is almost impossible in practice, the VRS DEA model is the model of choice in calculating municipal efficiency.

A choice also has to be made between input or output oriented measures. Input-oriented measures focus on the quantity/amount by which inputs could be reduced without the reduction of output, while output-oriented measures address the increase of output quantities/amounts without increasing inputs. Due to an overall low-level of fiscal decentralization, even in most developed countries, studies to a major extent use output-oriented efficiency, as municipalities have limited possibilities to influence the level of budget revenues. This is very relevant for the $\mathrm{BiH}$ context as well due to the high dependency of $\mathrm{BiH}$ municipalities on upper governments transfers and the very limited possibility for raising taxes and charges at the municipal level. In addition to this restriction, there is an asymmetric distribution of revenues at the entity level, so a municipal efficiency estimation using input-oriented measures would not be an appropriate choice. As a result, for this study the output measure is used.

By using DEA, municipalities are recognized as efficient when they outperform all other municipalities in the sample and all possible linear combinations of all other jurisdictions. A municipality is efficient when it achieves a better overall performance than all other municipalities in the sample and is inefficient when it does not. The main logic of this approach is that inefficient municipalities may improve their performance in at least one of the dimensions measured. This depends highly on the conditions at which a municipality performs its tasks and the types of services that the municipality provides.

The selection of input and output variables for this study was limited to data collected under the same methodology across the country. Therefore, the most frequently used input and output variables in reviewed studies are checked for consistency in the collection methodology of statistical agencies in $\mathrm{BiH}$. According to a desk review of overall municipal efficiency studies, the single input used was either total or current expenditure. Bearing in mind the relatively limited level of capital expenditure at BiH's municipalities, total budget expenditure is used for this study. On the output side, the authors mainly used population, the number of pupils in primary schools, the length of roads, grant beneficiaries, and elderly care. For this study, the first three outputs are selected, while the number of grant beneficiaries could not be used due to the non-existence of data, and for elderly care the data on population by age is not consistently collected and therefore the number of doctors was used instead. The unit of analysis is the municipality and for the purpose of this analysis the fact that some municipalities have a status of "city" was not taken as relevant if these "cities" consist of only one municipality. The dataset consisted of 141 municipalities in $\mathrm{BiH}$. Bearing in mind the special status given to district Brcko, this municipality has been excluded from analysis.

For calculation of DEA-VRS efficiency the following combination of input and outputs were used:

Input variable (I):

- 11: Total budget expenditure - proxy for all inputs

Output variables $(0)$ :

- O1:Population - proxy for overall administrative services to citizens

- O2: Number of pupils in primary school - proxy for educational services 
Table 2: DEA inputs and outputs descriptive statistics

\begin{tabular}{|l|r|r|r|r|}
\hline Variable & Mean & St.dev & Min & Max \\
\hline I1: Total budget expenditures (in BAM) & 8.636 .879 & 10.951 .852 & 233.226 & 94.964 .650 \\
\hline O1: Population & 26.232 & 29.531 & 109 & 199.191 \\
\hline O2: Number of pupils in primary school & 2.093 & 2.381 & 0 & 15.651 \\
\hline O3: Length of roads in kilometres & 61 & 46 & 0 & 250 \\
\hline O4: Number of doctors & 43 & 105 & 0 & 844 \\
\hline
\end{tabular}

- O3: Length of roads in kilometres - proxy for quality of transport service

- O4: Number of doctors - proxy for health care services

DEA input and output descriptive statistics are presented in Table 2.

Total budget expenditure significantly varies, from 233.226 BAM in Istočni Mostar to almost 95 milion BAM in Banja Luka. The population size also ranges from 109 in Istočni Drvar to almost 200.000 in Banja Luka. There are 2 municipalities without pupils in a primary school (Istočni Drvar and Istočni Mostar), 4 municipalities without asphalt roads (Istočni Drvar, Istočni Mostar, Petrovac and Petrovo) and 8 municipalities without doctors (Bosansko Grahovo, Dobretići, Donji Žabar, Istočni Mostar, Jezero, Kupres-RS, Osmaci, Pelagićevo and Vukosavlje).

\section{BiH MUNICIPALITIES EFFICIENCY ESTIMATION}

The scoring of $\mathrm{BiH}$ municipality efficiency was done using the DEA ONLINE SOLVER and an output oriented DEA-VRS has been applied in calculating efficiency estimations for 141 municipalities. As is visible from the descriptive statistics of municipal efficiency scoring presented in Table 3, the average efficiency at the $\mathrm{BiH}$ level is 0.71 , the standard deviation is 0.21 and the lowest efficiency score was 0.09 .

Table 3: Descriptive statistics for DEA-VRS

\begin{tabular}{|l|r|}
\hline Mean & 0.71153 \\
\hline Median & 0.72988 \\
\hline Standard Deviation & 0.20816 \\
\hline Minimum & 0.09511 \\
\hline Maximum & 1 \\
\hline Count & 141 \\
\hline
\end{tabular}

The average estimated efficiency of $\mathrm{BiH}$ municipalities of 0.71 or $71 \%$ implies that by better usage of inputs, outputs may be increased by $29 \%$ to reach full efficiency. Figure 1 shows that only 23 municipalities or $16 \%$ are fully efficient, while 32 or $23 \%$ are extremely inefficient. Relative efficiency is exhibited by $13 \%$ of municipalities, confirming that the overall efficiency of $\mathrm{BiH}$ municipality is rather low, with $71 \%$ of municipalities being inefficient. Almost half of total municipalities scored (49\%) have efficiency scores lower than average.

Figure 1: Efficiency of BiH municipalities

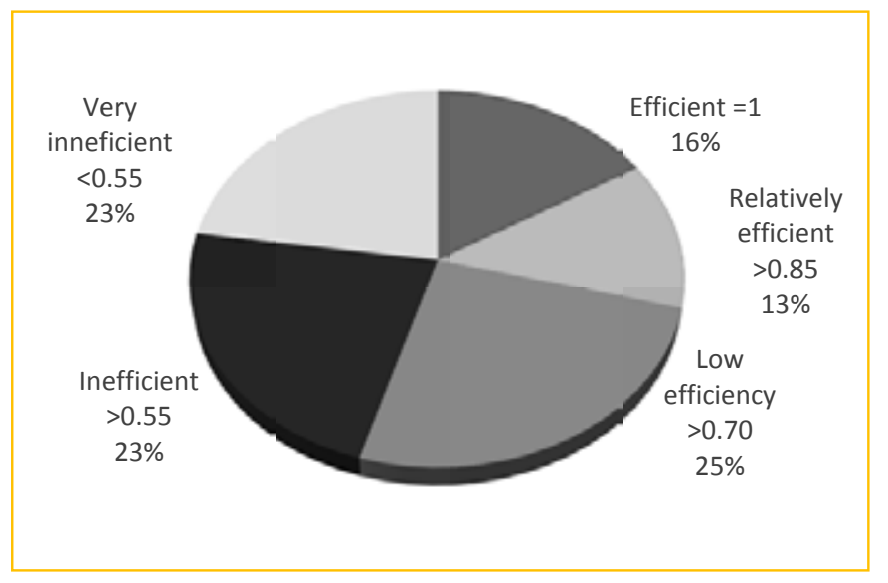

\section{The efficiency of newly created municipalities}

One of the major drivers of decentralization in $\mathrm{BIH}$ is the accommodation of ethnic interests to preserve peace and comply with newly the created borders of entities. In total, 33 new municipalities have been created by the DPA. Out of this number, 19 municipalities or $58 \%$ belong to the RS, while the remaining 14 or $42 \%$ belong to $\mathrm{FBiH}$. As presented in Table 4 , only 2 or $6 \%$ of newly created municipalities are efficient and the average efficiency of newly created municipalities $(0.60)$ is much lower than the estimated municipal efficiency of "old" municipalities (0.74).

Only 2 municipalities created after 1992 are efficient, Sapna $(\mathrm{FBiH})$ and Osmaci (RS), while 13 municipalities or $39 \%$ are very inefficient, i.e. with an efficiency score lower than 0.55 . As presented in Figure 2,60\% of municipalities created after 1992 are inefficient or very inefficient, $21 \%$ show low efficiency, while a further $18 \%$ are relatively efficient $(12 \%)$ or fully efficient (6\%). 
Table 4: Descriptive statistics: efficiency of new municipalities

\begin{tabular}{|l|c|c|c|}
\hline \multicolumn{1}{|c|}{} & $\mathrm{BiH}$ & \multicolumn{2}{c|}{$\begin{array}{c}\text { "New" } \\
\text { (created after 1992) }\end{array}$} \\
\hline Mean & 0.71153 & 0.60206 & 0.74498 \\
\hline Median & 0.72988 & 0.60784 & 0.74888 \\
\hline Standard Deviation & 0.20816 & 0.23732 & 0.18715 \\
\hline Minimum & 0.09511 & 0.09511 & 0.30789 \\
\hline Maximum & 1 & 1 & 1 \\
\hline Count & 141 & 33 & 108 \\
\hline Number of efficient & $\mathbf{2 3}$ & $\mathbf{2}$ & $\mathbf{2 1}$ \\
\hline \% of efficient & $\mathbf{1 6 \%}$ & $\mathbf{6 \%}$ & $\mathbf{1 9 \%}$ \\
\hline
\end{tabular}

Figure 2: Efficiency of municipalities created before and after 1992

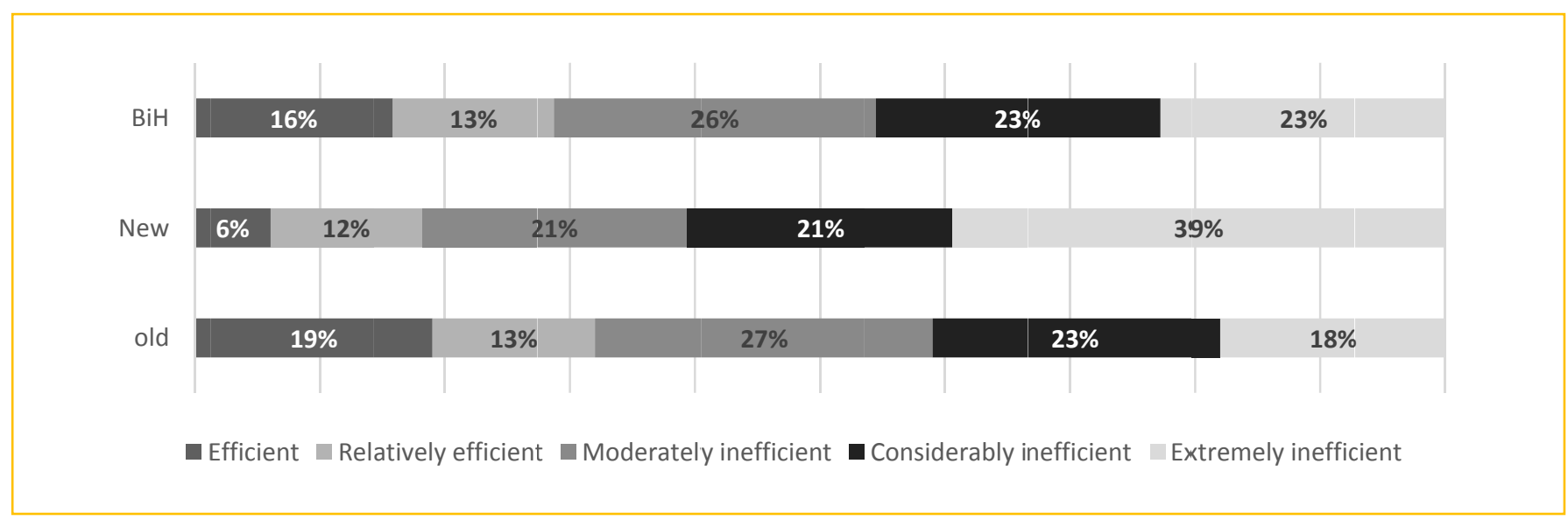

Municipalities with a longer history in principle have stronger institutional capacity and therefore are able to achieve better efficiency in using available inputs. New municipalities are in principle very small, having on average only 5,809 inhabitants. Newly created municipalities are very dependent on transfers from upper government levels. On average, these municipalities have only $27 \%$ of their own revenues in their budget and only eight have lower dependency on transfers than the $\mathrm{BiH}$ average (64\%). Almost half of municipalities, 16 in total, created after 1992 are dependent on budget transfers of $80 \%$ or more and only 2 are efficient in using provided inputs, while the vast majority $-82 \%$ of municipalities - are inefficient. Among municipalities that existed before 1992, only 10 or $9 \%$ depend on transfers of $80 \%$ or more and $69 \%$ are inefficient.

The creation of new municipalities, mainly driven by political and ethnic reasons, did not contribut to increased efficiency in the provision of municipal services and creating better conditions for $\mathrm{BiH}$ citizens. The low efficiency of $\mathrm{BiH}$ municipalities is even lower for newly created municipalities, with only two new municipalities or $6 \%$ actually efficient, with $12 \%$ having some level of efficiency and the remaining $82 \%$ inefficient, with a significant share (39\%) of municipalities extremely inefficient.

\section{DISSCUSION OF THE RESULTS}

The major changes in the administrative set up in $\mathrm{BiH}$ occurred after the Dayton Peace Agreement. The main aim of decentralization in $\mathrm{BiH}$ was primarily to accommodate ethnic aspirations and to preserve peace by creating more coherent ethnic administrative units of local government. This goal has been reached and strong ethnic concentration is in place in the vast majority of municipalities in $\mathrm{BiH}$. The ethnic structure municipalities significantly changed in the 2013 census in comparison to the 1991 census.

However, it is worth exploring the price paid to accommodate ethnic interests and aspirations in terms of citizens' wellbeing and its overall impact on economic development and quality in the provision of public services. To provide insight into determining if tolerance towards inefficiency was too high, with a negative impact on overall economic development, 
the following hypothesis has been set:

The aim of the Dayton Peace Agreement has been reached - the stability and integrity of $\mathrm{BiH}$ has been more or less preserved over the last 20 years. This should be a sufficient period to revisit the major assumptions of decentralization and return to one of the interesting concepts that arose from the decentralization process - the souffle theory, i.e. that it is time for the next attempt to reach a proper combination of ingredients for an efficient and enabling decentralisation framework.

Table 5 summarizes the major effects of decentralization in $\mathrm{BiH}$ in terms of the usual (dis)advantages of decentralization efforts, showing that increased democratization and political stability are the most important advantages of a decentralized design. The disadvantages are the complexity of tax reforms, increased public employment, as well as increased corruption and a strong conflict with macroeconomic policy.

It is important to mention that some of the local communities managed to simplify bureaucracy, increase public service quality and promote accountability. The number of such municipalities is not high, the gains in efficiency are overall highly dependent on local community and leadership, and these cases cannot be recognized as direct benefits of the decentralization process itself.

The division of some municipalities to accommodate ethnicity achieved increased political stability. Although this is perhaps a disputable point, it has helped significantly in the post-conflict period, where trust between ethnic groups was at a very low level. The strong polarization of ethnic groups due to forced migrations during war time has been preserved by the DPA. Figure 3 shows a comparison of the prevailing ethnic structure in municipalities according to the last two censuses.

Table 5: Summary of decentralization advantages and disadvantages in $\mathrm{BiH}$

\begin{tabular}{|l|l|l|l|}
\hline Advantages & Effects BiH & Disadvantages & Effects BiH \\
\hline Increases democratization & Relatively high & New charges & Moderate \\
\hline Simplified bureaucracy & Moderate & Fragmentation of internal markets & Moderate \\
\hline Better political representation & High & Increases corruption & Relatively high \\
\hline Increases political stability & Relatively high & Cross subsidizing & Moderate \\
\hline Better specialization of central government & Low & Complexity of tax reforms & High \\
\hline Increase in public services quality & Moderate & Conflict with macroeconomic policy & Relatively high \\
\hline Promotes accountability & Moderate & Increased public employment & High \\
\hline
\end{tabular}

Figure 3: Ethnic division by municipalities according to the 2013 and 1991 censuses

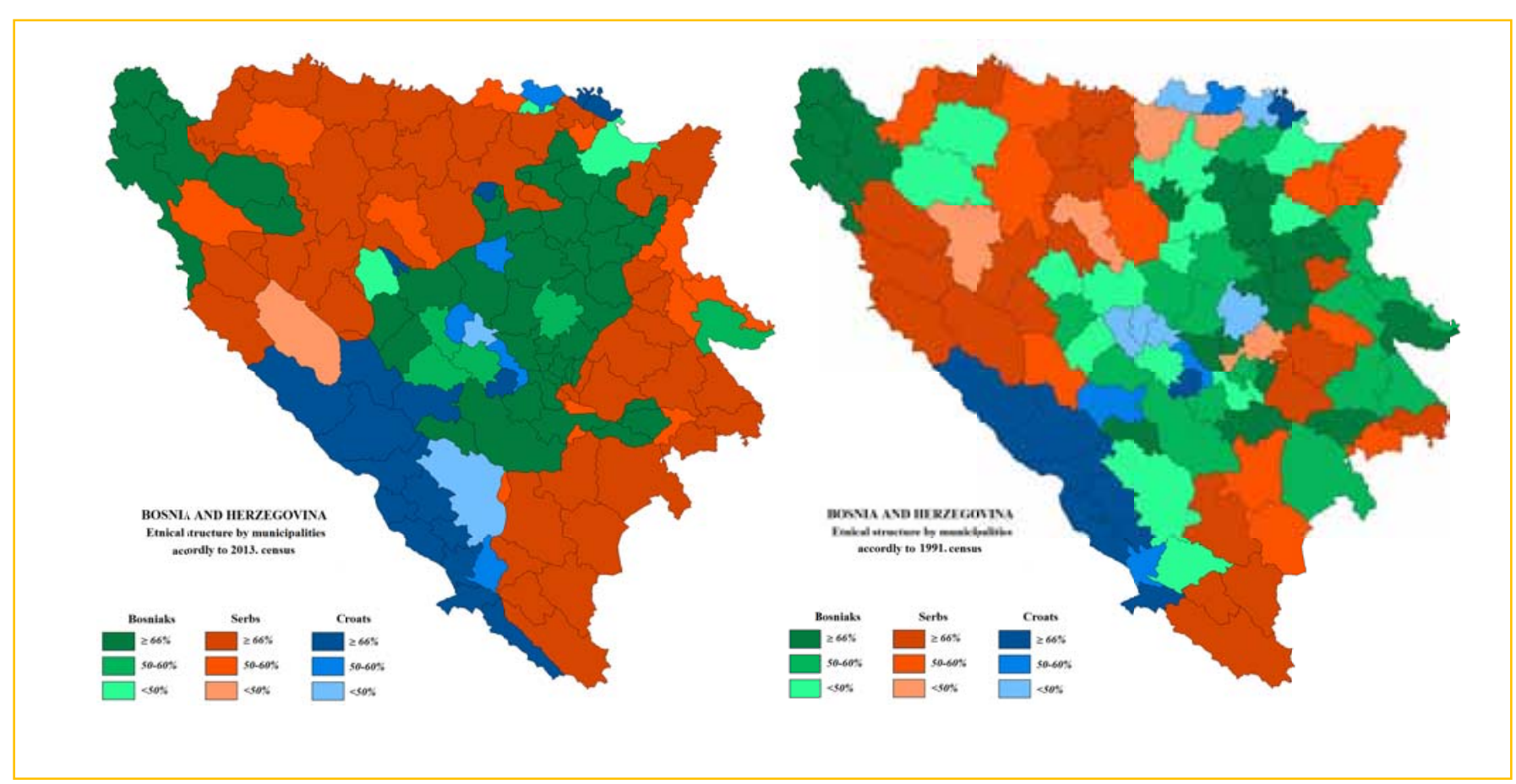


This illustrative comparison of ethnic majority by municipalities between the two latest censuses shows that decentralization indeed has contributed to the stronger concentration of ethnic groups. However, the findings of this study confirm that it did not help achieving efficiency and a higher economic scale. Quite the opposite, it has resulted in stronger ethnic cleavages and has become one of the major obstacles to economic development, not only at the municipal level, but also for the whole country. Interestingly, recent research in $\mathrm{BiH}$ confirms that ethnic diversity, where it still exists, has a positive impact on economy and social capital outcomes at the local level (Efendic 2018, Efendic and Pugh 2018).

Better specialization in the central government is not secured due to the tendency of weakening state level jurisdictions. Complex decentralization set up in $\mathrm{BiH}$ resulted in blurred accountability due to an overlapping of jurisdictions and the unclear responsibility of different levels of government, as well as a low level of coordination and harmonization mechanisms for horizontal and vertical cooperation. To overcome fiscal shortages, municipalities have imposed some quasi taxes and charges which differ significantly between local communities. There were several attempts to provide a map of para-fiscal charges in $\mathrm{BiH}$, but due to the relatively high autonomy of local communities in this regard, it was never completed.

One of the weakest points in the decentralization process in transition countries is the lack of a proper legal framework. Unclear responsibilities and the lack of key laws and regulations became a huge obstacle, one sometimes insurmountable to improving efficiency at the subnational level. Although in many cases EU Accession has proven a strong push factor for undertaking reforms and increasing public sector efficiency, the majority of decisions needed for the process of joining the $\mathrm{EU}$ are done on a copy/paste basis without proper preparation and transition to new solutions. $\mathrm{BiH}$ has taken a similar pattern, but at a much slower pace than other transition countries in the region. Indeed, the administrative set up designed under the DPA is complex, and significantly limits improvement possibilities.

Because of the DPA, central government capacity is weakened due to political reasons and state level functions are squeezed. In combination with low institutional capacity at the subnational level this results in the low efficiency of subnational government and slow economic development.

Among major system outcomes, decentralization in $\mathrm{BiH}$ has contributed only to better political representation in terms of direct election, while the other two important outcomes of political decentralization, transparency and accountability, are far from being reached. The same may be observed in the area of administrative decentralization, where none of the system outcomes have been reached - including administrative capacity, accountability and transparency.

In terms of fiscal and financial effects, decentralization further deepened the differences between rich and poor municipalities and made the system of resource mobilization and allocation complex and inefficient.

\section{CONCLUSIONS}

By using a DEA-VRS efficiency estimation, this study analyzed the effects of decentralization on average municipal efficiency in $\mathrm{BiH}$. A review of available literature and studies on measuring municipal efficiency was used as a basis to determine the proper methodology and data for the $\mathrm{BiH}$ context. The findings confirm low levels of average municipal efficiency in $\mathrm{BiH}$, with only $16 \%$ of municipalities identified as efficient. On average, BiH municipalities may increase their level of outputs by almost 30\% without changing inputs (budget expenditure). However, there is a lack of incentives for municipalities to increase efficiency as budget transfers are provided under defined criteria that are not related to municipal performance.

Municipalities established by the DPA exhibit significantly lower efficiency than "old" ones. On average, the municipal efficiency of DPA-created municipalities is 0.60 , which means that these municipalities with the same budget expenditure could increase outputs by around $40 \%$. The average efficiency of municipalities that existed before 1992 is 0.74 ; i.e., these municipalities have an efficiency gap of about $25 \%$. Out of the 33 newly created municipalities only six percent are efficient, while around $40 \%$ of newly created municipalities are very inefficient.

Bearing in mind that around $5 \%$ of the total population lives in newly created municipalities, it seems that a high price in terms of inefficiency is paid to accommodate the political and ethnic interests of arelatively low percentage of the country's total inhabitants.

The major limitation of the study is the lack of consistent data across the country due to fragmented data collection and asymmetric criteria for budgetary transfers. This has limited our choice of input and output variables, but still enabled the choice of the most frequently used variables in European studies on municipal efficiency. Further research could be done by including budget revenue in the analysis, while including prior adjustments in the model to make data comparable at BiH level. An analysis of efficiency 
in revenue collection and in particular own revenue component would provide useful insights on the potential of municipalities to exhibit efficiency on both the revenue and expenditure sides.

\section{REFERENCES}

Afonso, A. and Fernandes, S. 2008. Assessing and explaining the relative efficiency of Local Government. Journal of Socio-Economics 37 (5).

Akai, N. and Sakata, M. 2002.Fiscal Decentralization Contributes to Economic Growth : Evidence from StateLevel Cross-Section Data for the Unites States. Journal of Urban Economics 52(1): 93-108.

Alesina, A., Baqir, R., and Easterly, W. 2002. Redistributive public employment. Journal of Urban Economics 48: 219-241.

Balaguer-Coll, M.T., Tortosa-Ausina, E, and Prior, D. 2007. On the determinants of local government performance: $A$ two stage nonparametric approach. European Economic Review 51 (2): 425-451.

Bird R.M. and Vaillancourt, F. 1998. Fiscal Decentralization in Developing Countries: An Overview. Cambridge University Press 1-48.

Bird, R.M. 2010. Subnational taxation in developing countries: a review of the literature. Policy Research Working Paper 5450. World Bank: Washington, DC.

Brennan, G. and Buchanan, J. 1980. The Power to Tax: Analytical Foundations of a Fiscal Constitution. New York: Cambridge University Press.

Breton, A. 1983. Federalism versus centralism in regional growth. In Biehl, D., Roskamp, K.W., and Stolper, W.F., eds, Public Finance and Economic Growth: Proceedings of the International Institute of Public Finance Tokyo 1981. Detroit: Wayne State University Press.

Brueckner, J.K. 1982. A Test of Allocative Efficiency in the Local Public Sector. Journal of Public Economics 19 (1982): 311-331.

Burg, S.L.and Shoup, P.S. 1999. TheWarin Bosnia-Herzegovina: Ethnic Conflict and International Intervention. Armonk, N.Y.: M.E. Sharpe.

Cadez, S. and Czerny, A. 2010. Carbon Management Strategies in Manufacturing Companies: An Exploratory Note. Journal for East European Management Studies 15 (4):348-360.

Conyers, D. 1984. Decentralisation and Development: A review of the Literature. Public Administration and Development Vol. 4.

Canning, D. and M. Fay 1993. The Effects of Transportation Networks on Economic Growth. Columbia University Working Paper.
Dabla-Norris, E. 2006.The Challenge ofFiscal Decentralization in Transition Countries. Comparative Economic Studies 48: 100-131.

Dabla-Norris, E. and Wade, P. 2002. The Challenge of Fiscal Decentralisation in Transition Countries. IMF Working Paper No.02/103.

Davoodi, H. and Zou, H. 1998, Fiscal Decentralization and Economic Growth: A Cross-Country Study. Journal of Urban Economics 43:244-257.

Deprins, D. and Simar L. 1983. On Farrell measures of technical efficiency. Recherches Economiques de Louvain 49 (2): 123-137.

Easterly W. and Levine, R. 1997. Africa's Growth Tragedy: Policies and Ethnic Divisions. Quarterly Journal of Economics 111 (4): 1203-1250.

Ebel, R.D., and Yilmaz, S. 2002. On the Measurement and Impact of Fiscal Decentralization. World Bank, Policy Research Working Paper 2809, Washington, D.C.

Efendic, A. 2018. The role of economic and social capital during the floods in Bosnia and Herzegovina. In Dzihic, V. and Solska, M. (eds.) Crisis Governance in Bosnia and Herzegovina, Croatia and Serbia. The Study of Floods in 2014. Bern: Peter Lang.

Efendic, A. and Pugh G. 2018. The effect of ethnic diversity on income - an empirical investigation using survey data from post-conflict environment. Economics: The OpenAccess, Open-Assessment E-Journal 12 (2018-17): 1-34.

Fjeldstad, O.H. and Moore, M. 2008. Tax reform and state building in a globalized world. In Deborah Braütigam, Odd-Helge Fjeldstad and Mick Moore eds. Taxation and state building in developing countries. Cambridge: Cambridge University Press.

Hayden, R.M. 2005. Democracy without demos?. The Bosnian constitutional experiment and the intentional Construction of non-functional states. East European Politics and Societies 19 (2):226-59

Jin, J. and Zou, H. 2002. How Does Fiscal Decentralization Affect Aggregate, National, and Subnational Government Size. Journal of Urban Economics 52 (2): 270-293.

Kalb, A. 2010. The impact of intergovernmental grants on cost efficiency: Theory and evidence from German municipalities. Economic Analysis and Policy 40 (1).

Kluggman, J. 1994. Decentralisation: A survey of literature from a human development perspective. United Nations Development Programme Occasional Paper 13, Human Development Report Office.

Klun, M. 2004. Performance Measurement for Tax Administrations: The Case of Slovenia. International Review of Administrative Sciences 70 (3): 567-574.

Kolstad, I. and Fieldstad, O.H. 2006. Fiscal decentralisation and corruption: A brief overview of the issues. $\mathrm{CHI} \mathrm{CHR}$ Institute, Bergen, Norway.

Koopmans, T.C. 1951. Activity analysis of production and allocation. John Wiley: New York. 
Lane, J. E. 2000. New Public Management. London: Routledge.

La Porta, R., Lopez-de-Silanes, F., Shleifer, A. and Vishny, R., 1999. The Quality of Government. Journal of Law, Economics and Organization 15: 222-279.

Levy, B.2006. Governance, Corruption and cial Accountability. Presentation to the TFESSD Consultations. World Bank, Washington DC

Loikkanen, H.A., Susiluoto, I., and Funk, M. 2011. The Role of City Managers and External Variables in Explaining Efficiency Differences of Finnish Municipalities. Helsinki Center of Economic Research Discussion Paper No.312.

Lovell, C.A.K. 1993. Production frontiers and productive efficiency, in The Measurement of Productive Efficiency: Techniques and Applications (Eds.) H. Fried, C.A.K. Lovell and S. Schmidt. Oxford University Press, Oxford.

Mahabil, J. 2011. Measuring efficiency of local government expenditure; AN FDH Analysis of a sample of South African municipalities. In Technical report to financial and fiscal commission of SA.

Martinez-Vazquez, J. and McNabb, R. 2003. Fiscal decentralisation and economic growth. World Development 31.

Mauro, P. 1995. Corruption and growth. Quarterly Journal of Economics 110: 681-712.

Meloche, J., Vaillancourt, F. and Yilmaz, S. 2004. Decentralisation or Fiscal Autonomy? What Does Really Matter? Effects on growth and public sector size in European transition countries. World Bank Policy Research Working Paper 3254

Mill, J.S. 1861. Considerations on representative government in utilitarianism, liberty and representative government. J.M. Dent: London.

Musgrave, R. 1959. The theory of public finance. New York: McGraw-Hill

Nieswand, M. and Seiferd, S. 2011. Some determinants of intermediate local government spending efficienc: Evidence from French departments. DIW Berlin discussion paper 1130 .

Oates, W.E. 1972. Fiscal Federalism. New York: Harcourt, Brace, Jovanovich.

Prud'homme, R. 1995. The Dangers of Decentralization. World Bank Research Observer 10 (2): 201-220.

Raboca, H.M., Lazar I., Lazar P.S. and Zagan-Zelter, D. 2010. An Exploratory Analysis of the Management Capacity Within the Local Public Administration from Romania. Transylvanian Review of Administrative Sciences, No. 31E: 133-146.

Rodriguez-Pose, A. and Gill, N. 2003. The global trend towards devolution and its implications. Environment and Planning, Government and Policy 21: 333-351.

Ruggiero, J. 2007. A comparison of DEA and the stochastic frontier model using panel data. International Transactions in Operational Research 14 (3): 259-266.
Schoepflin, G. 1993. The rise and fall Yugoslavia. In McGarry, J., O'Leary, B., The politics of Ethnic Conflict Regulation. Case Studies of Protracted Ethnic Conflicts. London and New York.

Seabright, P. 1996. Accountability and decentralisation in government: An incomplete contracts model. European Economic Review 40 (1): 61-89.

Shah, A. 2004. Fiscal decentralisation in developing and transition economies. World Bank policy research working paper 3282.

Simar, L. and Wilson, P.W. 1999, Of Course we can bootstrap DEA scores! But does it mean anything ? Logic trumps wishful thinking. Journal of Productivity Analysis 11: 93-97.

Simon, H. 1946. The Proverbs of Administration. Public Administration Review 6 (1).

Simonsen, S. G. 2005. Addressing ethnic divisions in postconflict institution-building: Lessons from recent cases. Security Dialogue 36(3): 297-318.

Smoke, P. 2013. Why theory and practice are different: The gap between principles and reality in subnational revenue systems. International Center for Public Policy Working Paper 13-13.

Taylor, F.W. 1911. The Principles of scientific management. New York: Harper and Brothers.

Thiessen, U. 2003. Fiscal decentralisation and economic growth in high income OECD countries. Fiscal studies 23 (3).

Tiebout, C. 1956. A pure Theory of Local Expenditures. Journal of Political Economy 64 (5): 416-424.

Treisman, D. 2002. Defining and Measuring Decentralisation: A Global Perspective, Working Paper, University of California Los Angeles, CA.

Tullock, G. 1969. Federalism: problems of scale. Public Choice 6: 19-29.

UNDP 2008. Decentralization in the Europe and CIS Region. Discussion Paper, Democratic Governance Practice, Bratislava Regional Centre.

Väyrynen, R. 1991. New Directions in Conflict Theory: Conflict Resolution and Conflict Transformation. London: Sage.

Weber, M. 1922. Economy and Society: An Outline of Interpretive Sociology. Berkley, California Press, USA.

Wolff, S. 2012. Consociationalism: Power sharing and selfgovernance', in Wolff, S. and Yakinthou, C. (eds.) Conflict Management in Divided Societies: Theories and Practice, London: Routledge.

World Bank n.d. Decentralisation toolkit. Retrieved from: http://www1.worldbank.org/publicsector/decentralization/toolkit9.pdf. 